\title{
Kajian Dampak Sanitasi Total Berbasis Masyarakat Terhadap Akses Sanitasi di Kabupaten Wonogiri
}

\author{
Ichwanudin ${ }^{1}$ \\ ${ }^{1}$ Mahasiswa Program Magister Kesehatan Lingkungan Fakultas Kesehatan Masyarakat, Universitas Diponegoro \\ Info Artikel : Diterima September 2016 ; Disetujui September 2016 ; Publikasi Oktober 2016
}

\begin{abstract}
Title: The Impact Study of Community Based Total Sanitation to Sanitation Access in District of Wonogiri.

Background: Enhancement number of achievement sanitation access in District of Wonogiri decrease every years in the last three years. Enhancement sanitation access in 2012 was 4,1\%, 2013 was 3,1\% and 2014 was 1,6\%. While the improvement of sanitation facility growth in 2013 and 2014 only 1,3\%. This research aimed to describe various enabling factors of Community Based Total Sanitation (CBTS) to sanitation access enhancement in District of Wonogiri.

Method: It was an analytic observational research with cross sectional design. The samples were 7 members of "AMPL" organization, 25 people from the sub-district government agency and 73 people from the village government agency. The data were analyzed by Mann-Whitney test, Kruskall Wallis test and Correlation Pearson.

Results: Based on the researh, AMPL managed the organization performance well. The CBTS sub-district managed the organization up to $68 \%$ while the village only $25 \%$. Sanitation access policy realitation in the sub-district was $24 \%$ and in the village 25\%. Sub-district government rating that Public Health Care Headman with big contribution in sanitation access enhancement was $48 \%$ and the village government was $29 \%$. the average of BOK funding allocation enhancement is 44\%. Only one sub-district had organized the capacity building.

Conclusion: the analysis results refer to the CBTS managing the organization performance, Policy, Capacity Building in sub-district and village, Public Health Care Headman policy, no different in the contribution for the sanitation access in District of Wonogiri. While the BOK funding allocation enhancement does not influence the sub-district sanitation access enhancement in District of Wonogiri.
\end{abstract}

Keywords: Sanitation access; CBTS organization; Policy; Capacity Building; Wonogiri

\section{PENDAHULUAN}

Pembangunan sanitasi di Indonesia menjadi masalah yang relatif kompleks. Karena masalah yang dihadapi bukan hanya menyangkut banyaknya variabel yang berpengaruh terhadap kinerja dan keberlanjutan pembangunan sanitasi dan higiene, tetapi juga adanya perbedaan masalah, bobot serta cara penanganan antara satu daerah dengan lainnya, sehingga sangat sulit dan tidak relevan untuk membuat sebuah model yang sama untuk diterapkan di semua kabupaten. Sejak diterapkan otonomi daerah pada Januari 2001, masalah sanitasi bukan lagi menjadi urusan Pemerintah Pusat, tetapi menjadi urusan wajib bagi pemerintah kabupaten sesuai UU No. 32/2004 tentang Otonomi Daerah. Namun masih banyak pemerintah kabupaten yang belum mampu mengurus dan memecahkan masalah di bidang sanitasi dan higiene. Seringkali bidang higiene dan sanitasi lebih merupakan isu marginal yang tidak memperoleh prioritas pembangunan. ${ }^{1}$

Masyarakat miskin di wilayah perdesaan dan perkotaan memiliki akses yang rendah terhadap pemanfaatan sanitasi. Lebih dari 30 tahun, akses terhadap sanitasi tidak berubah. Berdasarkan Joint Monitoring Program WHO-UNICEF pada tahun 2007, akses sanitasi tetap pada angka 38\%. Capaian laju perkembangan seperti ini Indonesia tidak akan berhasil mencapai MDG's untuk sanitasi. ${ }^{2}$ 
Selama periode tahun 1992-2007 di Indonesia penyakit diare selalu masuk tiga besar proporsi penyakit penyebab kematian balita 0-59 bulan. Untuk mencegah penyakit infeksi terutama diare, tindakan aktif para pihak terkait secara serempak, komprehensif dan berkualitas sangat dibutuhkan. Menurut Jaya menyatakan bahwa penerapan intervensi untuk peningkatan nutrisi balita, penyediaan air bersih, sanitasi dan bahan bakar rumah tangga yang ramah lingkungan akan menurunkan kematian angka kematian balita 14 persen di Amerika Latin dan Karibia, 24 persen di Asia Tenggara, 31 persen di Afrika . ${ }^{3}$

Jenis jamban yang digunakan rumah tangga turut mempengaruhi tingkat keparahan diare pada Balita. Jenis jamban tersebut ada dua yaitu, baik dan buruk. Jenis jamban baik yaitu jamban yang dilengkapi dengan tangki septik, sedangkan jamban buruk yaitu jamban yang tidak dilengkapi tangki septik. ${ }^{4}$

Sanitasi lingkungan merupakan faktor yang menentukan status gizi anak. Sanitasi lingkungan yang buruk dapat memicu terjadinya penyakit infeksi yang akhirnya akan mempengaruhi status gizi anak. Hal ini sejalan dengan penelitian yang dilakukan oleh Triska (2005) yang menyatakan bahwa akibat sanitasi yang tidak memadai menyebabkan semakin tingginya penyakit infeksi yang akan berpengaruh terhadap kesehatan. $^{5}$

Secara umum akses sanitasi dasar atau jamban di Kabupaten Wonogiri cukup baik bila dibandingkan dengan wilayah kabupaten lainnya di Provinsi Jawa Tengah. Namun masih cukup tertinggal bila dibandingkan dengan Kabupaten yang berdampingan langsung di Provinsi Jawa Timur, yaitu Pacitan dan Magetan. Kedua Kabupaten tersebut sudah memiliki $100 \%$ akses sanitasi.

Pemerintah Kabupaten Wonogiri memiliki komitmen dan target bahwa maksimal pada tahun 2017 masyarakat Wonogiri memiliki 100\% akses sanitasi. Upaya pemenuhan komitmen dan target yang telah dicanangkan mulai menghadapi kendala yang ditunjukkan dengan semakin turunnya marjin perkembangan akses sanitasi dalam tiga tahun terakhir. Selisih perubahan akses sanitasi pada tahun 2012 sebesar 4,1\%, tahun 2013 sebesar 3,1\% dan tahun 2014 sebesar $1,6 \%$.

\section{MATERI DAN METODE}

Jenis penelitian ini adalah observasional dengan pendekatan secara cross sectional, yaitu pengamatan dengan pengukuran berbagai variabel dilakukan satu kali atau disatu waktu untuk mengetahui perbedaan akses sanitasi antara sebelum dan sesudah implementasi Sanitasi Total Berbasis Masyarakat.

Penelitian ini merupakan penelitian terapan (Applied Research) karena penelitian diarahkan untuk mendapatkan informasi yang dapat digunakan untuk memecahkan masalah. ${ }^{6}$

Populasi penelitian ini adalah parapihak (Stakeholder) program STBM yang ada di Kabupaten
Wonogiri. Di tingkat kabupaten adalah Pokja AMPL, di tingkat kecamatan Pokja STBM adalah Camat dan di tingkat desa adalah Kepala Desa.

Sampel penelitian ini adalah para pihak di tingkat kecamatan. Struktur pemerintah kecamatan yang sudah heterogen (terdiri dari beberapa sektor) dan memiliki peranan besar dalam proses perencanaan dan evaluasi pembangunan merupakan pertimbangan utama dijadikan sampel. Jumlah pengambilan sampel di tingkat kabupaten berdasarkan perwakilan satuan kerja perangkat daerah anggota Pokja AMPL, di tingkat kecamatan menurut krijcie table sebanyak 24 kecamatan. Namun di tingkat kecamatan akan dilakukan total sampling, jadi pengambilan sebanyak 25 kecamatan, dan diperoleh sebanyak 73 subyek.

\section{HASIL DAN PEMBAHASAN \\ Organisasi Pengelola Air Minum dan Penyehatan Lingkungan (OPAMPL)}

Evaluasi OPAMPL Kabupaten Wonogiri diikuti oleh 7 responden yang merupakan anggota aktif. Hasil evaluasi mrnunjukkan partisipaif pengelolaan OPAMPL dapat diterima dengan beberapa kemungkinan perbaikan, kecuali pada poin sistem informasi yang masih memerlukan perbaikan pada aspek tertentu.

Kajian terhadap subsistem informasi dan pengambilan keputusan diarahkan untuk mempelajari proses pengambilan keputusan strategis pada sebuah organisasi (keputusan kunci). Untuk pengambilan keputusan strategis, diperlukan informasi yang akurat dan menyeluruh tentang organisasi, terutama tentang bagaimana sistem yang ada dalam organisasi dapat tetap berjalan sesuai dengan misinya mencapai tujuan yang telah ditetapkan. ${ }^{7}$

\section{Organisasi Pengelola STBM Kecamatan}

Proporsi kecamatan yang sudah memiliki organisasi pengelola STBM kecamatan adalah $68 \%$. Kecamatan yang sudah memiliki organisasi pengelola STBM kecamatan dan terjadi peningkatan akses paling besar adalah Kecamatan Pracimantoro. Sedangkan kecamatan yang belum memiliki organisasi pengelola STBM kecamatan namun terjadi peningkatan akses sanitasi paling besar adalah Kecamatan Karangtengah.

Penyebab rendahnya peningkatan akses sanitasi di tingkat kecamatan disebabkan dua hal, yaitu proporsi kecamatan yang belum memiliki organisasi pengelola STBM masih besar dan kinerja organisasi pengelola STBM belum optimal. Lima belas dari tujuh belas organisasi pengelola STBM kecamatan mengalami kendala dalam pengorganisasian.

Pengorganisasian adalah suatu langkah untuk menetapkan, menggolongkan dan mengatur berbagai macam kegiatan, penetapan tugas dan wewenang seseorang dan pendelegasian wewenang dalam rangka mencapai tujuan. Fungsi pengorganisasian merupakan alat untuk memadukan (sinkronisasi) semua kegiatan yang beraspek personil, finansial, material dan tata 
cara dalam rangka mencapai tujuan yang telah ditetapkan. ${ }^{8}$

\section{Organisasi Pengelola STBM (Gerakan Serentak Sanitasi Masyarakat Bersama dan Total) Desa/ Kelurahan}

Jumlah tim atau organisasi Gerakan Serentak Sanitasi Masyarakat Bersama dan Total (Gertak Sambal) desa/ kelurahan yang terbentuk di setiap kecamatan masih belum sesuai jumlah desa/ kelurahan yang ada di Kabupaten Wonogiri. Hanya ada tiga kecamatan yang proporsi Gertak Sambalnya mencapai $100 \%$, yaitu Wuryantoro, Paranggupito dan Kismantoro. Wilayah kecamatannya belum memiliki Gertak Sambal namun memiliki proporsi peningkatan akses sanitasi yang paling besar adalah Kecamatan Karangtengah. Sedangkan yang sudah memiliki proporsi Gertak Sambal $100 \%$ dan memiliki peningkatan akses sanitasi tertinggi adalah Kecamatan Kismantoro.

Penyebab rendahnya peningkatan akses sanitasi di tingkat desa/ kelurahan disebabkan beberapa hal, yaitu: 1) kebijakan Peraturan Bupati nomor 12 Tahun 2015 tentang STBM belum terdiseminasikan dengan baik, 2) kelengkapan administrasi dan perangkat organisasi belum menjadi prioritas pemenuhan, 3) hasil kegiatan pemicuan yang tidak segera ditindaklanjuti dengan pemberian opsi solusi.

\section{Kebijakan Pemerintah Kecamatan dan Desa}

Sebagian besar kecamatan belum memberikan kebijakan tertulis untuk mendukung peningkatan akses sanitasi dalam pengembangan STBM. Enam kecamatan dari 25 kecamatan telah memiliki kebijakan atau sebesar 24\%. Kondisi demikian tidak jauh berbeda dengan realisasi kebijakan di tingkat pemerintah desa.

Rendahnya realisasi kebijakan pemerintah kecamatan dalam upaya peningkatan akses sanitasi dapat dipengaruhi dua hal utama, yaitu: 1) perbedaan persepsi terhadap pemahaman kebijakan yang telah ada, 2) suatu kebijakan akan mengandung konsekuensi mobilisasi sumber daya

\section{Kebijakan Kepala Puskesmas}

Sebanyak 16\% kecamatan menilai kontribusi kebijakan kepala puskesmas terhadap peningkatan akses sanitasi masih kecil karena belum ada kebijakan, inisiasi serta turut serta dalam proses atau kegiatan peningkatan akses sanitasi secara langsung.

Rendahnya angka kepala puskesmas yang berkontribusi besar terhadap upaya peningkatan akses sanitasi di desa dilatar belakangi oleh ekspektasi besar para pemerintah desa terhadap kehadiran kepala puskesmas di tengah masyarakat. Masyarakat yang paternalistik masih menilai bahwa figur kepala puskesmas masih memberikan pengaruh yang kuat sebagai tokoh masyarakat.

Nilai tambah ketika kepala puskesmas dapat hadir di tengah masyarakat adalah terciptanya interaksi yang lebih erat sehingga identifikasi masalah bisa lebih mendalam kemudian bisa jadi referensi tambahan mendesain intervensi dengan lebih tepat sasaran dan efisien.

Pemimpin organisasi adalah individu yang menciptakan budaya organisasi. Strategi fungsi yang dijabarkan dalam program kegiatan organisasi pada setiap periode merupakan suatu perwujudan dari asumsi dasar (keyakinan) yang dimiliki oleh pimpinan organisasi. Pelaksanaan program pencapaian tujuan organisasi sangat tergantung pada kepemimpinan yang ada dalam organisasi. Kepemimpinan dan budaya organisasi tidak ubahnya sebagai mata uang yang pada satu sisi dan sisi lainnya memiliki nilai yang sama. Keterlibatan individu dalam organisasi sangat ditentukan oleh kapasitas sumber daya yang dimiliki oleh anggotanya. Semakin tinggi tingkat kemampuannya semakin tinggi pula keterlibatan seseorang dalam organisasi tersebut dan sebaliknya. ${ }^{9}$

\section{Alokasi Dana STBM}

Total dana pendukung kegiatan STBM dari Dinas Kesehatan pada tahun 2013 sebesar Rp 110.380.000,-.Pada tahun 2014 sebesar Rp 36.414.000,-. Pada tahun 2015 sebesar Rp 25.000.000,-, sedangkan pada tahun 2016 sebsar Rp 36.400.000,-. Dana berasal dari sumber lain (BOK) periode tahun 2014-2015 sebesar Rp 476.606.118,--

Alokasi dana STBM belum memberikan dampak terhadap akses sanitasi secara langsung atau signifikan. Daya dukung sanitarian terhadap pengelolaan alokasi dana BOK masih belum optimal. Sanitarian yang memiliki kemampuan yang cakap dan kinerja yang baik akan dapat memilih strategi dan jenis kegiatan yang lebih efektif dan efisien. Pengelolaan administrasi turut mempengaruhi kesiapan dan serapan dana. Rentang waktu kesiapan dana dapat mempengaruhi efektivitas program atau kegiatan.

Selain itu, daya dukung tim puskesmas turut mempengaruhi pencapaian akses sanitasi. Ada beberapa kegiatan yang persiapan hingga penyelenggaraannya membutuhkan bantuan dari tim. Dukungan yang kuat akan menciptakan sinergi program, sehingga walaupun nilai alokasi dana BOK untuk STBM suatu puskesmas tidak terlalu besar, namun bisa tetap memberikan pengaruh peningkatan akses.

\section{Peningkatan Kapasitas}

Upaya peningkatan kapasitas bagi pengelola di tingkat kecamatan baru satu kecamatan yang menyelenggarakannya, yaitu Kecamatan Manyaran. Sedangkan di tingkat desa masih belum ada yang menyelenggarakannya.

Sangat rendahnya realisasi peningkatan kapasitas bagi pengelola STBM di tingkat kecamatan atau desa sangat mempengaruhi kinerja organisasi pengelola STBM. Pelatihan pada dasarnya adalah proses transformasi pengetahuan, sikap dan keterampilan. 
Tiga hal tersebut merupakan faktor yang menentukan produktivitas sumber daya manusia, sehingga apabila tidak ada upaya peningkatan kapasitas pengelola, maka peningkatan akses sanitasi akan terhambat.

\section{SIMPULAN}

Penelitian ini menyimpulkan bahwa kinerja organisasi pengelola Air Minum dan Penyehatan Lingkungan (AMPL) sudah baik di semua aspek penilaian evaluasi. Realisasi organisasi pengelola STBM tingkat kecamatan (68\%) dan desa $(25 \%)$ tidak dapat memberikan perbedaan pada peningkatan akses sanitasi di kecamatan $(1,55 \%)$ dan desa $(1,1 \%)$.

Adanya kebijakan pemerintah kecamatan (24\%) dan desa (25\%) tidak dapat memberikan perbedaan pada peningkatan akses sanitasi di kecamatan $(1,55 \%)$ dan desa $(1,1 \%)$

Besarnya kontribusi kepala puskesmas ke kecamatan (43\%) dan desa (29\%) tidak dapat memberikan perbedaan pada peningkatan akses sanitasi di kecamatan $(1,55 \%)$ dan desa $(1,1 \%)$.

Besaran peningkatan alokasi dana BOK untuk STBM (43\%) tidak mempengaruhi peningkatan akses sanitasi di tingkat kecamatan $(1,55 \%)$ dan desa $(1,1 \%)$. Peningkatan kapasitas tidak dapat memberikan perbedaan pada peningkatan akses sanitasi. Kepada pengelola STBL disarankan untuk menyusun rencana kerja lanjutan guna meningkatkan kapasitas penegelolaan.

\section{DAFTAR PUSTAKA}

1. Kemenkes RI. Road Map Percepatan Program STBM 2013 - 2015. 2013: Jakarta
2. Juniar, Midia. Studi Tentang Implementasi Program Sanitasi Total dan Pemasaran Sanitasi (StoPs) dalam Perspektif Deliberatif di Desa Ngampungan Kecamatan Bareng Kabupaten Jombang . ISSN 2303 - 341X. Volume 1, dNomor 1, Januari 2013.

3. Djaja, S., Wiryawan, Y. dan Maisya, I. Tren Penyakit Penyebab Kematian Bayi dan Balita di Indonesia Dalam Periode Tahun 1992 - 2007.

4. Irianto, Joko dkk. Frekuensi Diare Ditinjau dari Beberapa Faktor yang Mempengaruhinya. Jurnal Ekologi Kesehatan, Vol 1, No 2, Juni 2002: 77-84.

5. Ch Rosha, Bunga dkk. Analisis Determinan Underweight Anak 0-23 Bulan Pada Daerah Miskin di Jawa Tengah dan Jawa Timur. Jurnal Ekologi Kesehatan Vol. 11, No 1, Maret 2012 : 63-72

6. Sugiyono. Metode Penelitian Administrasi. Alfabeta., Bandung, 2006.

7. Muninjaya, Gde. Manajemen Kesehatan Edisi 2. EGC, Jakarta, 2004.

8. Muninjaya, Gde. Manajemen Kesehatan. EGC, Jakarta, 1999.

9. Thoyib, Armanu. Pembangunan Pertanian Berbasis Pada Sumberdaya Manusia untuk Mendukung Otonomi Daerah Dinamika Pedesaan dan Kawasan Vol 2 No 2, 2002. 